\title{
Tim Winton's Narrative of Belonging: Revisiting Australian Identity through Europe in The Riders
}

\section{Sarah Zapata, University of Zaragoza}

The Riders, Tim Winton's popular novel published in 1994 and short-listed for the Broker Prize in 1995, is largely based on Winton's personal experience in Europe while working on his previous novel Cloudstreet (1991). Winton together with his wife Denise and their son Jesse travelled around Europe visiting France, Ireland and Greece during the late eighties. Unlike his earlier fiction, The Riders is set in Europe and deals with the story of an Australian family that decides to settle down in Ireland after having been travelling around Europe for a couple of years. The novel begins with the main protagonist, Fred Scully, refurbishing the cottage they have just bought in County Offaly, Ireland, while his wife Jennifer and their sevenyear-old daughter Billie return to Australia to sell their Fremantle house. However, on the day that Jennifer and their daughter are due to arrive, only Billie turns up at Shannon airport, forcing Scully to come to terms with the fact that his wife has deserted them. The greater part of the novel focuses on Scully's attempt to find his wife. Thus he heads off with his daughter on a tour around Europe, visiting all the places where they had been before. Finally, he does not find his wife, so by the end of the novel he abandons the search and returns to their cottage in Ireland in order to start a new life with his daughter. 
The purpose of this paper is to explore the way in which Tim Winton's novel, The Riders, enhances a certain construction of Australian identity by establishing a set of contrasts between Australia and the European continent. I also intend to explore how Winton's novel tackles a very recurrent theme in Australian literature: the centrality of the land and belonging in defining identity.

The Riders portrays Scully's journey through Europe searching for his wife in a way that seems to stress the cultural and historical differences between the two continents, emphasising the sense of displacement and emotional dislocation felt by the protagonist for being in an unfamiliar, alien environment. In an interview, Winton commented on the impact of his visit to Europe in terms of displacement:

When I got to Europe I knew the moment I set my foot down that I wasn't European. I'd been brought up all my life to think that I was a European. I'm not even faintly European. I looked at the glories of Europe from behind a smoky glass. It was like this huge gulf; I admire but it wasn't hugely connected with me. I felt torn, almost, like torn out of the soil from home. Then when I came back I knew what was going on. I knew if I stayed away too long I'd be adrift, and I felt like I was going to wither up and die. I knew this is where I belong. I know my continent, I know my country, I certainly know my landscape as to what it means to me. (Hefner 1991:23)

This experience in the old continent made Tim Winton realise how the Western Australian landscape gives him his bearings and a very strong sense of belonging. As he acknowledges: "I'm connected to the land and the landscape and the sea, and the colour of the light, and the smell of the eucalypts, the whole thing. I wouldn't say it's a kind of new Aboriginality, I wouldn't even feel that I had to even chase after the term, but it's a feeling of belonging" (Hefner 1991:23). In an interview with Eleanor Watchel Winton explains Scully's psychological and emotional displacement in the following terms: "If you take him out of his landscape, you put him twelve thousand miles from home, in the wrong climate, it's winter, everything's wrong. So nothing that he'd taken for granted in his life, nothing that props him up as a person, is left" (1997:76).

Cut off from his familiar environment, Scully feels dislocated and undergoes an identity crisis. The portrait of Scully as an Australian with a strong sense of place and belonging reveals Winton's commitment to place, the local and the community in his work. The novel brings to the fore how place and the land give Scully a sense of identity, of who he was in the past, who he is at present and who 
he will be. Since the very beginning the novel sets out Scully's homesickness after two years in Europe:

In the hedge beside him two small birds wheeled in a courting dance. He recognized them as choughs. He mouthed the word, resting a moment and rubbing his hands. Choughs. Strange word. Two years and he still thought from his own hemisphere. He knew he couldn't keep doing it forever. He should stop thinking of blue water and white sand; he had a new life to master. (1994:11)

This scene clearly shows how Scully constantly recalls his life back home in Australia with nostalgia and longing. However, the narrative focuses on his unsuccessful attempts to accommodate his Australian identity within a hostile European background. His sentimental longing for his homeland is also revealed the day he receives mail from home, in Western Australia. His mother's postcard which "showed the Swan River at dusk with the lights of Perth budding against a purple sky" (55) and another card from his daughter move him deeply. The Riders, through Scully's experience, also offers a particularly interesting treatment of displacement, placing the European continent as the strange and harsh land, something commonly applied to Australia. The novel presents an Australian man attempting to come to grips with the old continent, reversing thus the usual literary and historical tradition which depicts Australia as the strange new land to be discovered and conquered. For Scully, it is Europe, not Australia, which is not only odd but also decadent and deteriorated.

Throughout the narrative Winton attempts to articulate a model of Australian identity for Scully by means of a set of contrasts between Europe and Australia. Two sets of values are constructed in opposition to each other. Europe stands for civilization, culture, historical monuments, sophistication, artificiality, elite and hierarchies. In contrast, Australia stands for wildness, nature, the land, naivety, authenticity, working-class and democracy. Within these binaries, Scully's wife, Jennifer, could be read as a counterpart to Scully. Her European artistic aspirations and her pretensions to high culture are set against Scully's working-class, practical and naïve Anglo-Irish Australian identity.

Scully's feeling of estrangement and his inner tension and turmoil due to the disappearance of his wife is reflected on by his comments on the several European cities they visited. He stresses the different conceptions of the land in Europe and Australia. He claims that Europeans are influenced by architecture and, on the contrary, Australians by the land. For instance, he compares the natural surroundings of his native country with the historical monuments and architecture 
that characterise Europe: "Scully had long thought that architecture was what you had instead of landscape, a signal of loss, of imitation. Europe had it in spades because the land was gone, the wildness was no longer even a memory. But this ... this was where architecture became landscape" (49). As the narrative develops, Scully insists on the image of Europe as a country anchored in the past: "Here the wildness was pressed into something else, into what had already been. And out there beneath the birds, in the gibberish of strokes and lines and connections of the valley was his new life" (51). In contrast, Australia is represented as a new country open to the future: "In Australia you looked out and saw the possible, the spaces, the maybes" (51).

Scully's journey could be read as an odyssey in quest of the truth. His journey begins in Greece. His image of the country is exclusively negative since he tries to establish a parallel between Greece and Australia: both countries are islands, sunny places with a similar geography. He also mentions that Greece "is like Australia invaded by the Irish" (73), a place where "nothing works and no one gives a shit" (73). He recalls how he worked for a stonemason humping granite up a hill while Jennifer tried at painting. Scully travels to Hydra, where he meets a group of British expatriates who settled on the island. One of the expatriates, Arthur Lipp recalls Scully and his family as "those strange Australians" (120), "the original innocents abroad" (120) and "A family of primitives" (121). Furthermore, he defines Scully as "my little convict mate" (133) with "primitive manners" (136) and Australia as still "the colony". Lipp somehow despises Scully because "he was just unnaturally sanguine and goodnatured to the point of irritation [...] so easygoing as to appear lazy" (120). Alex Moore, another expat in Greece, defines him with the "patience of Job and the face of the Cyclops" (163), acknowledging that there's "[s]omething terribly provincial in that kind of niceness" (163). Scully feels somehow intimidated, misunderstood by the expats, and in their presence he feels "the complete farmboy, the toolslinger, the deckhand" (131). Consequently, the meetings that Scully has with European people enhance and heighten the cultural differences with Australia reasserting Scully's Australian identity. In the novel, the Europeans are portrayed as arrogant, unpleasant, snobbish and hierarchical people that disapprove of Scully's innocent, vulnerable and good nature creating a stereotype for him as a "working-class boofhead with a wife who married beneath herself, a hairy bohemian with a beautiful family, the mongrel expat with the homesick twang and ambitious missus, the poor decent-hearted bastard who couldn't see the roof coming down on his head" (10).

From Greece Scully and his daughter travel by ferry to Brindisi, in Italy, and then to Florence, where he receives a telegram from Jennifer to meet her in Paris. In 
Paris, Scully also suffers the hostility and arrogance of the French. For him, Paris was a "damn place" (71), "a black hole" (72), where he did "shit work all day so [Jennifer] could write" (72). To Scully it is just "a place, a town whose traffic noise and street fumes reached him at a faint remove" (260). He perceives visible signs of decadence and perversion everywhere. For instance, when Billie needs to go to the toilet, they go into a café whose owner was "a fat man with earrings and peroxided curls" (263). Billie cannot find the ladies' room, since there are men in both rooms. The problem is that it is a homosexual café and Scully thinks it is not a very appropriate place for his daughter, since he sees degeneration everywhere. The fact that the city is built on the catacombs, mines and cemeteries also stresses the metaphor of death implied in the history of the French capital. They felt the hostility of French people towards them. As Billie recalls, they were not happy in Paris "where no one liked them and the sun would never go down at night" (207). Before changing the setting to Amsterdam, Billie develops a fever and Scully decides to phone Marianne, one of Jennifer's friends when they stayed in Paris and for whom he worked for a while. When Marianne, whose name should represent the national leitmotif of 'Liberty, Equality and Fraternity', sees Scully with Billie she is very reticent to help them, but finally she calls a doctor for the child. Suddenly, Scully recalls how he told "redneck stories against himself and his country" (278) to Marianne's friends, who "were amusing yuppies, handsome, curious and unlike people they'd known before" (278). As he acknowledges: "For a while he felt almost exotic at Marianne's parties, but it wore off in the end, playing the part of the Ignoble Savage" (278). Although Scully criticises and judges European decadence, this scene shows how he sometimes tries to cling to some sort of 'national identity' perpetuating the myths about Australia and the Australian people.

As Scully negotiates the old, unattractive historical buildings and landscapes within Europe, he is also trying to come to terms with his own identity and with his wife's desertion. Scully's impressionistic descriptions of Amsterdam, another place where Jennifer might possibly be, are even worse and more disapproving than those of Paris. The depiction of Amsterdam's central station highlights the extremely critical treatment given to the various European cities in the novel:

Ghetto blasters and guitars reverberated in every corner. Junkies and drunks lay nodding in hallways. [...] A madman in fluorescent tights shrieked at his own reflection in the windows of the closed-up Bureau de Change. Hippies of seventeen and eighteen who looked German to Scully swilled Amstel and laughed theatrically amongst themselves. [...] The air was warm and foul with 
body odour, smoke and urine so that the street air was a sweet blast to be savoured a second or two. (326)

In Amsterdam, Scully shows clearly visible signs of mental as well as physical deterioration. In Scully's words the city is "the Auschwitz of the mind, the place you'd never dreamt of going, the hell they said wasn't real" (340). Their stay in Amsterdam echoes Dante's descent into hell, distorting Scully's mental state leaving him wandering like a Jew around the city. It is Billie that puts order to Scully's shattered life and makes him regain control of his life. Scully and Billie do not find Jennifer in Amsterdam, so they decide to return to Ireland, which represents their new homeland. The novel brings to the fore the way in which the hostility of the European cities and their historical backgrounds stress Scully's depiction as an outcast, an alien or outsider in the old continent. As Igor Maver argues in his article "Tim Winton's 'European' Novel The Riders" (1999), Winton presents Europe "as a symbol of personal defeat, social decadence and spiritual and physical deterioration" $(1999,102)$.

The physical journey of Scully searching for his wife not only becomes a search for meaning but also for identity, since all the experiences he has to go through make him confront and accept his Australian identity. This quest for identity is encoded in the novel's narrative. In The Riders, Winton clings to the Anglo-Celtic voice which has been dominant within the construction of the Australian national identity for centuries, in order to ground Scully's white Australian identity in Ireland's historical past. Scully's trip of self-discovery into the recognition and the reassertion of his roots and his sense of belonging to his mother country is made through the establishment of similarities with Ireland. Scully's empathy with Ireland is made patent in the novel. The circular structure of the novel, which begins and ends in Ireland, is also relevant. Ireland provides him with a home. The opening description of the bare hill where Scully's eighteenth century peasant cottage stands reminds the reader of the pastoral, bucolic Irish countryside. There is also a gothic castle in ruins near Scully's cottage that stresses the mysterious atmosphere of the place. Winton's Ireland has nothing to do with contemporary Ireland; it is a rural, mythic and pastoral Ireland. As Jennifer Rutherford states in her article "The Colonising Victim: Tim Winton's Irish Conceit", unlike the European cities Scully visits, Ireland "floats, unattached and uncontaminated by European snobbism, inauthenticity and elitism" (2001:158).

In The Riders, we, therefore, find Ireland as "buttress, as ally, and as homeland" (156). In Ireland, Scully finds recognition, welcome and hospitality. For instance, he makes friends with the local postman, Pete-the-post and spends happy moments 
with him fixing the cottage. Similarly, Ireland and Australia share an attitude, an affinity to nature and landscape. Scully feels nostalgia for eucalypts, the Australian sea and sky. The novel constantly emphasises Scully's need to go back and belong to the Australian land.

The opening pages of the novel are reminiscent of the Australian colonial tradition. Scully is repairing a cottage "older than his own nation" (1994:4). Scully is renovating his house; he is transforming old into new. He is shown mending the place he owns with his bare hands. With this image Winton seems to recall the British colonisers who built up the Australian nation, making a new country. On the one hand, Winton offers the image of an Australian "colonising" an ex-colony. While Scully is clearing the mildew, refuse and decay, he remembers his life back home. He starts singing the only Irish song he knows, The wild colonial boy, whose lyrics epitomise the figure of the bushranger: "a native son, who, carrying the stain of an Irish rebel tradition, defies the law" (Rutherford 2001:157). This song also makes reference to colonial Australia.

On the other, Winton also attempts to draw another connection with Ireland by showing both Ireland's and Australia's shared status as colonial 'Other'. According to Rutherford, by borrowing Ireland's status as a victim of colonisation Winton denies Australia's real history of colonisation and the history of cultural Aboriginal dispossession in Australia in order to reassert the legitimacy of white Australian narratives of national identity. Winton identifies both countries as the colonised other emphasising the fact that both are subject to the oppression and marginalisation by Europe. In The Riders, Europe and England are featured as the colonisers of Australia and Ireland in order to reverse the traditional image of white Australians as colonisers. Winton attempts to reverse this by depicting Scully, an Australian in Europe, as a victim of colonisation. One day Scully receives a postcard from his daughter, who is still in Australia. The picture represents the Round House in Fremantle, an old jail that was built on the beach to welcome the convicts before they were sent to Rottnest, an island off Perth, in the nineteenth century. This aspect of Australian history could be read as a metaphor for the present situation of Scully in Europe, who is abandoned by his wife and trapped in a place he first bought for her sake. Reversing the traditional representation of convicts in Australia, Scully is like a convict sent to Europe. He is imprisoned in the old continent, thus reversing history. The postcard's key sentence, "Do not Fall off the edge Scully" (56), is also very telling since it anticipates Scully's descent into hell during his journey around several European cities. 
In conclusion it could be said that Winton's novel The Riders endorses a very particular kind of Australian identity grounded in the Anglo-Celtic tradition. Winton articulates a version of Australian identity that favours naivety, vulnerability and practicality and forges a new narrative of belonging by drawing a parallel between Ireland and Australia. The novel also brings to the fore the intimate relationship of Australians to the land, and how place and identity give Winton's characters a strong sense of belonging.

\section{Bibliography}

Hefner, R (1991). "Winton on Cloud Nine after Reviews." Canberra Times. April $21,23$.

Maver, Igor (1999). “Tim Winton's 'European' Novel The Riders." Commonwealth Essays and Studies. Spring, 21.2, 101-108.

Rutherford, Jennifer (2001). "The Colonising Victim: Tim Winton's Irish Conceit". In Anne Luyat and Francine Tolron, eds. Flight From Certainty: The Dilemma of Identity and Exile, Rodopi Perspectives on Modern Literature, 23. Amsterdam: Rodopi, 153-163.

Watchel, Eleanor. 1997. "Eleanor Watchel with Tim Winton". Malhat Review. Winter, 121, 63-81.

Tim Winton. 1994. The Riders. London: Picador. 